\title{
Um mapa das relações entre o rap das periferias de São Paulo e o samba
}

\author{
[A map of the relations between the rap from the \\ outskirts of São Paulo and the samba
}

\section{Walter Garcia ${ }^{\mathrm{I}}$}

RESUMO $\cdot O$ artigo tem por objetivo mapear as relações que o rap produzido na cidade de São Paulo estabeleceu, desde a década de I990, com o samba. Em perspectiva interdisciplinar, o mapa apresenta e discute sete pontos: I) a importância do samba para a formação musical de MCs e DJs; 2) a presença do samba e do rap em bailes black e, posteriormente, em gravadoras que se originaram de equipes que organizavam estes bailes; 3) a função política e social da música nos momentos de lazer de bairros periféricos; 4) canções que buscaram fundir rap e samba em suas formas; 5) canções e discos que buscaram justapor rap e samba, o que tornou mais evidentes as diferenças; 6) conflitos entre o rap e o samba atravessados por questões de etnia, de ideologia, de mercado ou de gênero; 7) a noção de que o pagode e o rap construíram juntos uma identidade masculina negra periférica. PALAVRAS-CHAVE - Música popular brasileira; crítica cultural materialista; rap; samba; sociedade brasileira contemporânea. · ABSTRACT
- The main purpose of this paper is to discuss the relationships that rap produced in the city of São Paulo established with samba since the I990s. In the interdisciplinary perspective that one takes, the map presents and analyses seven points: I) the importance of the samba for the musical formation of MCs and DJs; 2) the samba and the rap in black parties and later in record companies; 3 ) the political and social function of the music in leisure time, in the outskirts of São Paulo; 4) the forms of songs that sought to mix the rap and the samba; 5) the senses of songs and albums that sought to juxtapose the rap and the samba; 6) the conflicts between the rap and the samba caused by ethnic and racial relationships, ideological disputes, competitions in music market or gender relationships; 7) the contribution of the "pagode" and the rap to peripheral black male subjectivity construction. KEYWORDS - Brazilian popular music; materialist cultural criticism; rap; samba; Brazilian contemporary society.

Recebido em I9 de abril de 2018

Aprovado em Io de agosto de 2018

GARCIA, Walter. Um mapa das relações entre o rap das periferias de São Paulo e o samba. Revista do Instituto de Estudos Brasileiros, Brasil, n. 70, p. 208-229, ago. 2018.

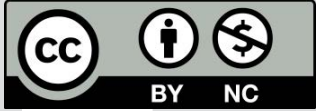

DOI: http://dx.doi.org/IO.II606/issn.23I6-90IX.voi70p208-229

I Universidade de São Paulo (USP, São Paulo, SP, Brasil). 
Em 20I7, durante o debate que se seguiu à mesa "Samba e comunidade", dentro do Colóquio Repensando o "Popular”, uma das perguntas encaminhadas pela plateia questionou o lugar do samba no processo de ressignificação das culturas das periferias de São Paulo a partir da década de $1990^{2}$. Participando da mesa, Chapinha, um dos fundadores do Samba da Vela, respondeu que o samba é "instrumento de formação da cidadania” tanto quanto outras práticas artísticas. E que Sergio Vaz adotou a máxima "Aqui o silêncio é uma prece", do Samba da Vela, quando criou o sarau da Cooperifa, em 200 ( (com Marco Iadoccico, conhecido como Marco Pezão)3.

Partindo do pressuposto, sabidamente batidíssimo, de que o samba é o gênero musical que se tornou, por excelência, símbolo da nacionalidade brasileira ${ }^{4}$, o tema nada tem de simples. Para ficar na consideração mais óbvia, abordá-lo em sua complexidade implicaria o exame das relações entre os vários estilos de samba e diversas expressões artísticas - as artes dos quatro elementos do hip-hop (DJs, MCs, $b$-boys e b-girls, grafiteiros e grafiteiras), os diferentes gêneros musicais produzidos nas periferias, a literatura, o teatro, o pixo, além de modalidades culturais (como cinema, balé, coral, orquestra, banda) que passaram a ser oferecidas nesses bairros “onde 'educação é artigo de luxo"” (BOTELHO; GARCIA; ROSA, 20I6, p. I77 e I85).

Permanecendo nos limites de contribuição ao tema, este artigo tem por objetivo mapear as relações que o rap de São Paulo vem estabelecendo com o samba - tomado como gênero musical, na sua pluralidade de estilos. Para tanto, foram pesquisados

2 O Colóquio Repensando o "Popular” foi promovido pelo Laboratório Interdisciplinar do Instituto de Estudos Brasileiros da USP nos dias 26 e 27 de outubro de 20I7. Realizada no primeiro dia do evento, a mesa "Samba e comunidade" contou com as participações de Amailton Magno Azevedo, Ana Elisa Camargos, Chapinha, Carlos Pires (mediação) e Rachel Sciré (mediação).

3 Sobre o Samba da Vela, consultar: Campos (2013). Não é o caso de desenvolver o assunto, mas note-se a proximidade entre o bordão "Aqui o silêncio é uma prece" (escrito no bar de Chapinha, local onde a roda do Samba da Vela se realizava de 2000 até 2002, e depois em um cartaz, na Casa de Cultura de Santo Amaro, onde a roda passou a ser realizada) e o espiritismo. Sobre a criação do sarau da Cooperifa e, nele, a adoção do mote do Samba da Vela, consultar: Nascimento, Érica (20II, p. 60-62) e Leite (20I4, p. 43-47 e 49).

4 O fato de já fazer parte do senso comum não torna, é óbvio, o tema irrelevante para a pesquisa acadêmica. Para três estudos esclarecedores, consultar: Sandroni (20I2), Cunha (2004) e Fenerick (2005). 
discos, canções, peças teatrais, entrevistas com artistas, debates e estudos produzidos desde a década de I990. Do conjunto, extraíram-se sete pontos que condensam um processo marcado por alianças e tensões (D’ANDREA, 20I3a, p. 77-78, 239-247).

\section{OUVINDO RÁDIO, TOCANDO NA LATA}

O primeiro desses pontos é a presença recorrente do samba na formação musical e, de modo mais amplo, nas práticas sociais, culturais e políticas de MCs e DJs que viveram a infância e a adolescência em bairros periféricos paulistanos, nas décadas de I970 e I980. Citarei seis casos exemplares.

Mano Brown, que nasceu no ano de I970 e que cresceu no bairro do Capão Redondo, na zona sul de São Paulo, com "I5 pra I6 anos" estava "sempre duro, desempregado, aí ia no samba, cantava, comia, bebia, arrumava namorada” (MANO BROWN, 20I7). Então, comprou um repique de mão e chegou a pensar em seguir no mundo do samba (MANO BROWN, 20I7)5. Não seguiu, como se sabe. Mas, segundo diria em entrevista (NOS TEMPOS DA SÃO BENTO, 20I0)' , a experiência lhe valeu quando passou a frequentar a estação São Bento do Metrô, "primeiro epicentro de hip-hop no Brasil”, território "para compartilhar e comungar ideias" (BOTELHO; GARCIA; ROSA, 20I6, p. I79-I80) e também para resolver conflitos (SILVA, I998, p. 59-63): Mano Brown foi um dos jovens que, não dispondo de rádio ou de outros equipamentos, tocavam na lata de lixo de metal que tinha, conforme ele recordaria, "uma sonoridade cabulosa" (NOS TEMPOS DA SÃO BENTO, 20Io).

Antes de Mano Brown, Thaíde já tocara "na lata de lixo da São Bento" para a Back Spin, equipe de break de que então participava, e já cantara rap ao som da lata. Para tocar, Thaíde fez uso da sua experiência com o atabaque, que aprendera no candomblé (ALVES, 2004, p. 45) ${ }^{8}$. Além disso, afirmou que o samba, o forró e o (hoje chamado) brega foram os ritmos com que se identificara durante a infância, na década de I970?.

5 Nessa entrevista, concedida em 20I7, Mano Brown afirma que "Tocava bem, era partideiro, improvisava meia hora. Eu fazia freestyle no samba. Eu era bom nisso. Tinha um monte de rima. Meu rap já vem daí, com palavras complexas. Não era rima pobre, não” (MANO BROWN, 20I7). Note-se que ele se refere à habilidade de improvisar no partido-alto. Sobre a composição de canções no mundo do samba, a recordação de Brown, em entrevista concedida em 2000, expôs outro sentimento: "Eu tentei fazer uns sambas, mas não deu... Samba é diferente. Eu aprendi a ser um cara ligeiro foi no rap" (MANO BROWN, 2000).

6 Sobre o assunto, assistir principalmente à passagem de 54:I6 a 55:3I do documentário de Botelho (NOS TEMPOS DA SÃO BENTO, 20I0).

7 Sobre o assunto, também consultar: Azevedo \& Silva (I999, p. 79-80).

8 José Carlos Gomes da Silva observa que tocar na lata de lixo "se tornou símbolo de identificação de uma geração, frequentemente utilizado para diferenciar a primeira geração de integrantes do movimento hip hop daqueles que vieram posteriormente” (SILVA, I998, p. 60).

9 Anotei a afirmação durante o debate “Samba e rap: parentes, vizinhos ou ilustres desconhecidos”, com Chapinha e Thaíde, no qual trabalhei como mediador. O debate ocorreu na Biblioteca Municipal Belmonte, na cidade de São Paulo, em I3 de setembro de 2008. 
Mas ouvia "principalmente os sambas da malandragem, como os Originais do Samba, a Fantástica Bateria, Jorge Ben, que é diferente do Jorge Ben Jor que se conhece hoje em dia". Thaíde afirmou ainda que, para ele, "começou uma revolução" quando ouviu o samba "Malandro", gravado por Jorge Aragão em I983: "Essa música dizia exatamente o que a gente vivia na favela: 'Malandro, eu ando querendo falar com você/ Você 'tá sabendo que o Zeca morreu/ Por causa de intrigas que teve com a lei'. Na periferia todo dia acontece isso e não é de agora" (ALVES, 2004, p. I9-20) ${ }^{\text {ro }}$.

Quando jovem, Thaíde morava "na Vila Missionária, zona sul da cidade" (ALVES, 2004, p. 26). Ele nasceu em I967, um ano depois de DJ Hum, com quem trabalharia de I988 a 2000. DJ Hum cresceu no município de Ferraz de Vasconcelos (BIONDI, I998, p. 20). Um dos "marcos da [sua] história pessoal" é a "experiência do samba e do soul como repertório de audição" desde a adolescência (AZEVEDO; SILVA, I999, p. 77-78) ${ }^{\text {II }}$. Sharylaine, que nasceu em I969 e também fez parte "da primeira geração de rappers" da cidade de São Paulo, atribuiu à família "o fato de, tendo contato com o mundo dos bailes, conhecer pessoas que a levaram para a estação São Bento do Metrô": seu avô “"tocava cuíca”; seu pai “"cantava samba” e "era mestre de bateria de escola de samba”; e sua mãe "saía na noite para cantar'" com um tio “"que era baterista” - "Quando eu nasci minha mãe já não cantava mais, mas meu pai ainda cantava"” (LIMA, 2005, p. 73-74) ${ }^{\mathrm{T2}}$.

Mais dois MCs complementam os exemplos. Sabotage nasceu em I973 e cresceu na favela do Canão, próximo ao Aeroporto de Congonhas. Com 15 anos, na década de I980, um samba de Chico Buarque "que tocava na rádio AM de [sua mãe] Dona Ivonete" chamou-lhe atenção: "Eu me via naquela música 'O meu guri', do Chico, e me imaginava cantando aquilo. Aquilo era o meu retrato no morro". Em outro momento, Sabotage afirmou ter escutado "muito samba, samba-rock", mas também que ensaiara as suas músicas "em cima de forró" ou de Leo Jaime. Já no ano 2000, ele e Mano Brown "planejaram fazer um rap" no som de "A tamba", gravado por Jorge Ben para o LP Samba esquema novo, de I963. Mas o projeto

Io No terceiro verso do samba, a memória de Thaíde substituiu "brigas" por “intrigas" (ARAGÃO, I983).

II Em I986, DJ Hum “já tocava numa das maiores equipes black de São Paulo, a Kaskata's, [e] entrou nas competições da São Bento como b-boy da Back Spin. [...] Depois da Kaskata’s, Hum foi ser DJ da Zimbabwe, onde começou a ganhar projeção e seguidores”. Em I988, a dupla Thaíde \& DJ Hum participou da coletânea Hip-Hop cultura de rua, lançada pela gravadora Eldorado, com duas faixas: "Corpo fechado" e "Homens da lei" (ASSEF, 2003, p. I8I-II9). Para os fonogramas, escutar: Vários (I988a).

I2 Fugiria aos propósitos deste artigo analisar a declaração da rapper sobre o pai haver continuado a cantar, e a mãe, não. $\mathrm{O}$ fato, porém, tem grande interesse à medida que aponta inequivocamente para relações entre a arte e a sobrevivência atravessadas por questões de gênero. Sharylaine "montou o primeiro grupo [de rap] formado só por mulheres, em I986, o ‘Rap Girl's”. Em I989, participou com “Nossos dias” do disco Consciência Black, lançado pela Zimbabwe (PINTO, 20I7). Para o fonograma, escutar: Vários (I989). 
“jamais se concretizou” (TONI C., 20I3, p. 29-30, 43-44, I98, II9) ${ }^{\mathrm{I3}}$. Criolo, que nasceu em I975 e foi criado no Grajaú, disse, em 20I7, que "sempre o samba estava presente: por amigos, pelos meus pais, pessoas dos barracos vizinhos... O samba que descrevia o nosso cotidiano, a nossa malandragem”. E citou, dentre outros, Martinho da Vila, Paulinho da Viola e Moreira da Silva (CRIOLO, 20I7a).

\section{EQUIPES DE BAILE, GRAVADORAS}

Vinculado ao primeiro ponto, o segundo desdobra o "mundo dos bailes" referido por Sharylaine. Nos anos I970, segundo o antropólogo José Carlos Gomes da Silva (I998) , "as equipes pioneiras [...] privilegiaram a black music norte-americana, o soul e o funk". Contudo, "em meio a estes gêneros, o baile black abria possibilidades para as apresentações de grupos nacionais de samba e outras práticas relacionadas à música negra". Quanto ao rap, os "eventos de grande porte" organizados pelas equipes de baile e a cultura de rua do hip-hop "permaneceram separados" até a passagem dos anos I980 para os anos I990. Nesse período, "por iniciativa da Chic Show, surgiu o Clube do Rap, um espaço no qual os grupos que estavam iniciando podiam mostrar seus trabalhos" (SILVA, I998, p. 70-74) ${ }^{\text {I4 }}$. Em I99I, segundo se lia na capa do caderno Ilustrada da Folha de S.Paulo, os bailes promovidos pela

I3 O som de Jorge Ben deve ser entendido a partir do "mundo do rap" e, portanto, na chave da construção de uma identidade étnica: trata-se de um artista negro "desde sempre difundido no mercado fonográfico hegemônico e que teve presença fundamental nos bailes organizados e frequentados por negros em São Paulo desde a década de I970" (GARCIA, 20II, p. 23I). Já o samba de Chico Buarque indica uma das questões complexas que atravessam este mapeamento: a relação entre o sistema da MPB e o processo de ressignificação das culturas das periferias. De um lado, duas das marcas deste processo são “a constituição de expressões artísticas próprias, que falam das periferias a partir de pontos de vista nela situados" e "a denúncia das condições de vida que, ao mesmo tempo, afirma a dignidade das pessoas que habitam estes bairros" (BOTELHO; GARCIA; ROSA, 20I6, p. I85). De outro, embora os valores da MPB venham se modificando desde a sua criação nos anos I960 (SANDRONI, 2004, p. 23-35), a sua consolidação, na década seguinte, definiu o vínculo com as classes médias dos grandes centros urbanos, "com acesso ao ensino médio e superior", herdeiras "de uma ideologia nacionalista integradora (no campo político)" e, entretanto, abertas "a uma nova cultura de consumo 'cosmopolita' (no campo socioeconômico)” (NAPOLITANO, 2002a, p. 2-3). Assim, via de regra e salvo exceções, os diversos pontos de vista que estruturam as obras da MPB olham as classes economicamente baixas do alto e/ou a distância, e nessas obras se expressa, por mais desconfortável que seja o lugar contemplado e descrito, a sensação de conforto (GARCIA, 20I3). As divergências, porém, não impossibilitaram contatos concretos entre o rap e a MPB, e algumas vezes o samba atuou como elo, com sentidos, alcances e problemas que variaram caso a caso. Para “O meu guri”, escutar: Buarque (I98I). Para “A tamba”, escutar: Ben (200I).

I4 Marcelo Segreto faz uma interessante análise da canção "Sr. Tempo Bom”, lançada em I996, ressaltando componentes da cultura black dos anos I970 e do hip-hop dos anos I980 exaltados na letra composta por Thaíde, assim como referências a programas de televisão e a espaços da cidade, além da citação de "Saudosa maloca” (Adoniran Barbosa). Além disso, Segreto descreve em profundidade os recursos de compatibilização entre a letra e a melodia mobilizados por Thaíde e DJ Hum (SEGRETO, 20I5, p. I05-II2). Para o videoclipe da canção, também lançado em I996, assistir a: Thaíde, DJ Hum (20I7). 
Kaskata’s mesclavam "rappers nacionais e estrangeiros" (LEITÃO, I99Ia), e havia a estimativa de que "mais de 80 mil pessoas" assistiam a shows de rappers em bailes black, a cada final de semana (LEITÃO, I99Ib) ${ }^{\text {I5 }}$.

Estruturando-se e capitalizando-se, algumas das equipes de baile se tornaram gravadoras, que, à margem do mercado fonográfico hegemônico, produziram coletâneas como A ousadia do rap, lançada pela Kaskata's em I987 (VÁRIOS, I987), O som das ruas, lançada pela Chic Show em I988 ${ }^{\mathrm{I}}$, e Consciência black, lançada pela Zimbabwe Colors em I989 (VÁRIOS, I989) ${ }^{\text {T. }}$. Para este último disco, o Racionais MC's realizou as primeiras gravações de "Pânico na zona sul" (de Mano Brown) e "Tempos difíceis” (de Edy Rock e KL Jay). A seguir, a Zimbabwe produziria os três primeiros LPs do Racionais: Holocausto urbano, em I990, Escolha seu caminho, em I992, e Raio X Brasil, em I993 (RACIONAIS MC'S, s.d.).

Nos limites deste artigo, não cabe discutir os problemas que surgiram nas relações comerciais entre diversos grupos de rap e gravadoras, que diversificaram a atuação das equipes de baile ${ }^{18}$. Importa destacar que algumas dessas gravadoras trabalhavam, ao mesmo tempo, com o rap e com o samba romântico. Citarei dois casos exemplares. O primeiro LP do Negritude Júnior, Jeito de seduzir, também seria lançado pela Zimbabwe em I992 (AZEVEDO; SILVA, I999, p. 73-74; NEGRITUDE JÚNIOR, I992). De forma semelhante, a RDS Fonográfica se dedicaria "predominantemente ao rap e ao pagode" distribuindo, dentre outros, os primeiros discos do Racionais e o primeiro LP do Art Popular, O canto da razão, lançado pela Kaskata's em I993 (VICENTE, 20I4, p. 249; ART POPULAR, I993).

Tanto o Art Popular quanto o Negritude Júnior, após o sucesso dos seus primeiros discos, seriam contratados pela major EMI, fato que será retomado adiante, no sexto ponto. Por ora, diga-se que a proximidade e que as diferenças entre o "mundo do rap" e o "mundo do samba" se mantiveram durante shows nas periferias paulistanas, ao longo da década de I990 e também na década seguinte. Algumas das equipes de baile contratavam "sambistas cariocas na ativa desde os anos 60 e 70, mas sem grande penetração na cidade, como Martinho da Vila, Dona Ivone Lara, Jovelina Pérola Negra, Almir Guineto, Zeca Pagodinho, Bezerra da Silva, Fundo de Quintal e Leci Brandão" (AZEVEDO; SILVA, I999, p. 73-74). E não era incomum que, fechando a noite, a atração principal fosse o rap, sobretudo quando o Racionais MC's se apresentava ${ }^{\text {I9. }}$.

I5 Para uma crítica do ponto de vista destas duas matérias jornalísticas, consultar: Santa Rosa (20I6, p. 39-4I).

I6 No momento em que escrevo, o disco não está disponível para audição no YouTube. Consultar: Vários (I988b).

I7 Para a trajetória da Chic Show e a da Zimbabwe, consultar: Félix (2000, principalmente p. 45-52).

I8 Sobre o assunto, consultar: Silva (I998, p. 70-76). Também consultar: Azevedo \& Silva (20I5, p. 2I9-220).

I9 Baseio-me em entrevista que realizei com Jé Oliveira, ator, dramaturgo e diretor de teatro, na sede do Coletivo Negro, cidade de São Paulo, em 27 de dezembro de 20I7. Jé Oliveira nasceu em I983 e cresceu em Mauá, município da região metropolitana de São Paulo. Mano Brown, em entrevista concedida ao Le Monde Diplomatique Brasil, recordou um show que fez com Bezerra da Silva e o que este lhe dissera: "Cadeia é que nem show, tem que 'tá lotado pra dar dinheiro" (MANO BROWN, 20I8). 


\title{
“O SAMBA AQUECE E O RAP DOMINA"
}

O terceiro ponto extraído do conjunto de textos pesquisados se vincula ao anterior mas coloca em evidência, primordialmente, a função política e social das músicas nos momentos de lazer dos bairros periféricos, na década de I990. Na hipótese radical de Tiarajú Pablo D’Andrea (2013a, p. I-57), frente ao aumento das taxas de homicídio, à hegemonia do neoliberalismo, ao "enfraquecimento dos movimentos sociais populares", ao esvaziamento das reuniões do Partido dos Trabalhadores (PT) e das Comunidades Eclesiais de Base (CEB) - frente a tudo isso, práticas culturais como o samba e o rap (mas também o futebol, a literatura, o teatro, as artes gráficas e as audiovisuais) reagiram, criando novos modos de produzir, difundir e obter "informação, autoconhecimento, denúncia e diversão" (D'ANDREA, 20I3a, p. I-57).

Pelo menos dois raps relatam essa experiência na chave do registro do cotidiano: "Fim de semana no Parque" (Mano Brown), lançado pelo Racionais MC's no disco Raio X Brasil, de I993; e "Ruas de fogo da periferia” (Ndee Naldinho), lançado por seu autor no disco Você tem que acreditar, de I997.

"Fim de semana no Parque" contou com a participação de Netinho, então integrante do Negritude Júnior. Uma reunião de pessoas tocando samba, recriada no momento em que Mano Brown narra que chegou à sua área, reforça a sensação de que ele, Brown, está entre iguais, sendo recebido em clima de euforia. Além disso, o samba também é materializado na divisão rítmica executada pelo rapper quando canta, fazendo uso de tercinas, parte dos versos que chamam a entrada do sambista. Isso ocorre três vezes, e a segunda delas é a mais significativa pela repetição do fonema /b/ e pelo uso de "bambambã": a palavra, que se originou do quimbundo mbamba-mbamba, "exímio, mestre" (HOUAISS; VILLAR, 200I), funciona como onomatopeia do repique de mão:

\author{
[Mano Brown] \\ É lá que moram meus irmãos, meus amigos \\ E a maioria por aqui se parece comigo \\ E eu também sou bambambã e o que manda \\ E o pessoal, desde às Io da manhã, está no samba \\ Preste atenção no repique, atenção no acorde \\ [Netinho] \\ Como é que é, Mano Brown?
}

\footnotetext{
20 É de minha responsabilidade a citação final, entre aspas, a qual atribui ao amplo processo estudado por D’Andrea objetivos e características do disco Raio X Brasil, do Racionais MC's, conforme Edy Rock enuncia na vinheta de abertura. Para o fonograma, escutar Racionais MC’s (s.d.) A partir da pesquisa que realizou com frequentadores e frequentadoras dos bailes promovidos pela Chic Show e pela Zimbabwe, na década de I990, João Batista de Jesus Félix notou outra dimensão do fenômeno: "O samba e o rap são tão somente diversão, e também símbolos de uma negritude que se difere mais por estilo do que por uma opção política” (FÉLIX, 200o, p. I02). Na apresentação do sexto ponto deste mapa, ficará mais compreensível em que medida a pesquisa de Félix coloca em perspectiva a hipótese de Tiarajú Pablo D’Andrea (20I3a).
} 
[Mano Brown]

Pode crer, pela ordem.

(RACIONAIS MC'S, s.d.) ${ }^{2 I}$.

Já em “Ruas de fogo da periferia”, Ndee Naldinho estabelece uma evidente oposição entre dois polos: do lado da treta e da confusão, a lei e a tevê quando invadem o bairro; do lado da alegria e da diversão, o samba e o rap tocados na praça e na esquina, lugares comunitários "que concorrem para a singularização do território e de suas forças" (SODRÉ, I998, p. I7), e também nas casas. Mas não deixa de haver certa hierarquia entre os gêneros, já que "Tem samba na praça (Tem)/ E na esquina/ O samba aquece e o rap domina” (NDEE NALDINHO, I997) ${ }^{22}$.

\section{"Pra onde Vou, fui e Vim"}

O quarto ponto reúne canções que têm na fusão de rap e samba a principal característica de suas formas. Exemplo notório é o trabalho de Rappin' Hood, desde quando integrava o Posse Mente Zulu, conjunto formado em I992 (BARBOSA, 200I) ${ }^{23}$. Três anos depois, em 20 de novembro de I995, no Vale do Anhangabaú, o Posse Mente Zulu apresentaria "Sou negrão" tendo por base rítmica o samba-funk, em um evento de comemoração pelos 300 anos da morte de Zumbi dos Palmares ${ }^{24}$. Em 200I, a canção seria gravada para Rappin' Hood em Sujeito homem, primeiro disco solo do rapper, com

2I Para interpretações mais amplas do rap “Fim de semana no Parque”, consultar: Garcia (20II) e D’Andrea (20I3b). Gabriel Lima Rezende chamou-me atenção para possibilidade de a divisão rítmica permanecer na indefinição, bem característica do samba, entre a tercina e o desenho de semicolcheia-colcheia-semicolcheia e também para a acentuação de Mano Brown na segunda nota da figura. A observação indica evidentemente que $o$ assunto carece de pesquisas mais aprofundadas.

22 Para informações mais completas sobre o disco Você tem que acreditar, consultar: Quintiliano (20I0). Para outra interpretação de "Ruas de fogo da periferia", consultar: Félix (2005, p. I39-I/I).

23 Sobre as posses, consultar: Silva (I999), Amaral (I998) e Amaral (2005).

24 Para o vídeo, produzido pela MTV do Brasil, assistir a Posse Mente Zulu (1995). Notar a grande multidão que participava do show no Anhangabaú. Uma entrevista interessante com o Posse Mente Zulu foi realizada para a série televisiva Música do Brasil. O programa também registrou “Sou negrão", em outra apresentação ao vivo (MÚSICA PARA RITUAIS DE ANTROPOFAGIA TECNOCULTURAL, 2000). 
participações de Leci Brandão, Moisés da Rocha e Sampagode (RAPPIN’ HOOD, 200I). A base, então, passaria a ser o ritmo que hegemonicamente é considerado "samba" No ano seguinte, 2002, o coletivo Instituto lançou o disco Coleção nacional (INSTITUTO, 20I3). Coordenado por Rica Amabis, Tejo Damasceno e Daniel Ganjaman, o projeto reuniu vários artistas, dentre os quais, Sabotage. "Dama Tereza", uma das duas faixas de que ele participou, é um dos exemplos mais perfeitos da efetiva fusão de samba e rap. Sem desmerecer os demais elementos da construção musical, isto se deve sobretudo à voz de Sabotage, que, ao enfatizar o som das palavras (no qual ressalta o fonema $/ \mathrm{i} /)^{26} \mathrm{e}$ a acentuação dos versos, transforma o canto em mais um instrumento melódico (jogando com o encadeamento de $\mathrm{G}_{7}$ e $\mathrm{C}_{7}$, que se mantém por toda a canção) e percussivo (jogando com a batucada).

Embora a sonoridade se sobreponha ao sentido intelectual da letra, é muito interessante notar que o refrão "Pra onde vou, fui e vim" comenta o encontro de Sabotage com, para citar apenas alguns dos nomes cantados, "Mestre Marçal", "Pixinguinha”, "Dona Ivone Lara”, "Tom Jobim”, “Sombrinha”, "Zeca Pagodinho”. E, ainda que o artifício didático mate a dimensão lúdica do canto e o seu poder de sugestão, não custa explicitar: "Pra onde vou", ao encontro de sambistas, já "fui” antes, todas as vezes que escutei seus sambas, "e vim" agora como um sambista da família do hip-hop ${ }^{27}$. Entre parênteses, o estudo da presença do samba no flow de Sabotage, ao longo de sua carreira lamentavelmente curta, ultrapassaria bastante

25 A base rítmica dessa gravação de “Sou negrão” (Rappin' Hood) é uma das variações do "paradigma do Estácio”, conforme denominação de Carlos Sandroni (20I2): reduzida a seus elementos mínimos, a base rítmica é formada por um ciclo de I6 pulsações, subdividido em dois grupos ímpares; o primeiro grupo tem 7, e o segundo, 9 pulsações. Advirta-se que, enquanto contribuição ao tema, este mapeamento não tem a pretensão de registrar todas as obras por meio das quais o rap produzido em São Paulo estabeleceu relações com o samba, e é incontornável que algumas canções, mesmo apresentando soluções originais, acabem não merecendo a devida atenção. Para ficar em três exemplos, escutem-se: a) “Território leste”, gravada pelo grupo Consciência Humana (2003), cuja forma é construída a partir do diálogo com o samba "Silêncio no Bexiga", de Geraldo Filme, cantado por Beth Carvalho com acompanhamento do Quinteto em Branco e Preto - para uma análise deste fonograma, consultar Segreto (20I5, p. 92); b) “Ā minha favela”, composição de Rappin' Hood que intercala a base instrumental do samba-rock, sobre a qual o rapper canta seus versos, e a base instrumental do samba, sobre a qual Péricles e Thiaguinho cantam versos de "Favela", composição de Arlindo Cruz, Ronaldinho e Acyr Marques (RAPPIN’ HOOD, 2005); c) “A arte do gueto”, lançamento independente de Ndee Naldinho e Art Popular (2009).

26 Segundo relato de Toni C., ao compor a letra de "Dama Tereza", Sabotage "começou utilizando a música "The Way I Am', de Eminem, como referência, mas para se aproximar das palavras inglesas terminadas com o som de ‘' foi necessário mutilar palavras e mudar a construção de frases”. A seguir, "Rica [Damasceno] aproveitou um momento de descontração quando Sabotage cantarolava um samba partido-alto para propor: 'Por que você não canta aquela música nessa melodia?”' (TONI C., 20I3, p. 2I2-2I3).

27 Em outra passagem de "Dama Tereza”, Sabotage canta: "Representando a fami”/ Sou do samba raiz/ Vou que vou, penso assim/ Hip Hop é meu hino/ Onde vou, 'tá comi'/ Olha lá, é assim”. O “artifício didático" que utilizo se baseia livremente em Candido (I996, p. 78). Sobre a dimensão lúdica do rap em geral, consultar Béthune (2004, p. 33-34). 
os propósitos deste artigo, mas poderia esclarecer aspectos fundamentais do meio pelo qual o rapper afirmava a sua presença e a sua identidade ${ }^{28}$.

Os exemplos finais deste quarto ponto vêm do trabalho de Emicida. Três faixas de seu primeiro CD, O glorioso retorno de quem nunca esteve aqui, lançado em 20I3, estabeleceram diálogos do rap com algumas das vertentes do samba: "Trepadeira", de Emicida e Felipe Vassão, com participação de Wilson das Neves; "Hino vira-lata", de Emicida, Beatnick e K-Salaam, com participação do Quinteto em Branco e Preto; e "Samba do fim do mundo", de Emicida e Felipe Vassão, com participações de Fabiana Cozza e Juçara Marçal (EMICIDA, 20I3a)29.

A forma de "Trepadeira" justapõe a base de samba-rock para a voz de Emicida, que radica no rap cantando as estrofes, e a de samba-sincopado para a voz de Wilson das Neves, que radica nesse mesmo estilo, cantando o refrão $0^{30}$. Junto da variedade rítmica, a canção se insere na constelação de sambas que repõem a imagem do homem como o macho provedor que estende "o tapete", dá "todo amor", trata "como flor", dá "sol e água" e, imagem que surge em complemento, a da mulher como a "rueira" que dá "mais do que chuchu", como a "costela de Adão [que] raspou o cabelo de Sansão". Sem estender demasiadamente o assunto, essa constelação vem desde, pelo menos, "Se você jurar" (de Ismael Silva e Nilton Bastos), samba gravado por Francisco Alves e Mário Reis para o carnaval de I93I (ALVES, REIS, I93I); inclui “Oh! Seu Oscar" (de Ataulfo Alves e Wilson Batista), gravado por Cyro Monteiro para o carnaval de I940 (VÁRIOS, I997), e "Mulata assanhada" (de Ataulfo Alves), gravado em ritmo de samba-jazz por Elza Soares e Wilson das Neves, com orquestra de Lyrio Panicalli, em I968 (SOARES; NEVES, I968); e se amplia com, dentre outros sambas, “A Rosa” (de Chico Buarque), lançado por Djavan e Chico em I980 (BUARQUE, 200I), e "Vai vadiar" (de Alcino Corrêa e Monarco), lançado por Zeca Pagodinho em I998 (PAGODINHO, I998) ${ }^{31}$.

Também a forma de "Hino vira-lata" trabalha com a justaposição do canto radicado no samba ${ }^{32}$, representado pelo Quinteto em Branco e Preto em coro, e

28 Na formulação, parafraseio análise de Christian Béthune sobre o flow no rap (BÉTHUNE, 2004, p. 82). No debate Samba e rap: parentes, vizinhos ou ilustres desconhecidos, em 2008, Chapinha afirmou que o samba e o rap eram irmãos; e comentou que "você ouve o pandeiro" quando escuta, por exemplo, Thaíde ou Rappin' Hood cantando.

29 Para informações sobre o disco, consultar: Emicida (20I7).

30 Para o clipe, assistir a: Emicida (2013b).

3I Ao estudar "Trepadeira” e indicar a constelação da qual a canção participa, espero não ser mal interpretado, o que poderia significar o rebaixamento da questão ao nível dos comentários irrefletidos em redes sociais. A observação também vale para os estudos, a seguir, de "Hino vira-lata" e "Samba do fim do mundo". Sem atentar para as referências culturais com que os três fonogramas dialogam, não há como compreender as diferentes relações que o rapper Emicida estabelece, a partir de quatro estilos de samba (samba-rock, samba-sincopado, variação do "paradigma do Estácio", samba-afro), com a MPB. De resto, não custa lembrar que estudar criticamente a forma de uma canção é procedimento muito diverso da atitude que, radicando no biografismo, atribui à pessoa do compositor ou à do intérprete um rótulo qualquer.

32 Refiro-me à divisão rítmica que hegemonicamente é considerada "samba", ou seja, à variação do "paradigma do Estácio" (SANDRONI, 20I2). 
do canto radicado no rap, representado por Emicida. De modo didático, pode-se apreender a distância entre um e outro quando se compara a primeira estrofe, entoada por Emicida, e a segunda, entoada pelo Quinteto. Já a base instrumental, ainda que não deixe de assinalar a diferença entre o "mundo do rap" e o "mundo do samba", é bem mais homogênea do que aquela que se escuta em "Trepadeira". Essa aproximação entre os dois gêneros, no plano da base instrumental, reforça o tema de "Hino vira-lata". Um tema já cantado tanto pelo samba quanto pelo rap: o do homem cuja "alma é escrava da boemia" e que celebra o seu encontro com a música, "luz que bem faz", ao mesmo tempo que reforça a imagem da mulher como aquela que é, lembrando Vinicius de Moraes, "Feita apenas para amar/ Para sofrer pelo seu amor/ E pra ser só perdão", tornando-se "referência de força e proteção" quando e se permanece "ligada à esfera doméstica" 33 .

Finalmente, "Samba do fim do mundo" justapõe o canto radicado no rap de Emicida, nas estrofes, e o canto na tradição do samba de Fabiana Cozza e Juçara Marçal, no refrão. Mas, desde a sua base instrumental e como um todo, trata-se de um samba-afro e, portanto, de um dos estilos da música negra. Dispondo lado a lado a voz masculina e as vozes femininas, a faixa se apresenta como um manifesto pela "reforma agrária da música brasileira", levando adiante, à sua maneira, a crítica da "máquina de moer pobre" e a da "guerra racial" 34 . Em resumo, os temas de "Trepadeira" e de "Hino vira-lata", estruturados por questões de gênero, colocam essas obras em linha com sambas que integram a chamada MPB. Já "Samba do fim do mundo" participa da constelação de obras que questionam de modo lúcido e mais ou menos agressivo, a partir da década de I990, a hegemonia dessa mesma MPB, um "complexo cultural plural" que sempre esteve vinculado às classes médias das grandes cidades mas, contraditoriamente, que se colocou "como medida do que deveria ser considerado 'popular' e 'brasileiro”” (NAPOLITANO, 2002, p. 72-75).

\section{“Fio da NAVAlha”}

Os quatro pontos apresentados até aqui exemplificam alianças que o rap de São Paulo vem estabelecendo com o samba. Deixando de lado particularidades e arriscando uma generalização, pode-se dizer que o conjunto se move em torno da experiência e da noção de que samba e rap são formas de sociabilidade e de consciência negras periféricas. A noção foi retomada pelo Racionais MC's na introdução de “Fio da

33 Para o clipe, assistir a: Emicida (20I3c). Os versos que cito são de "Samba da bênção", de Baden Powell e Vinicius de Moraes, gravado pelos autores em I963 (MORAES; LARA, 200I). Já os termos entre aspas, ao final da frase, são citações que faço de Waldemir Rosa (2006, p. 67-69). Talvez não fosse necessário esclarecer, mas diga-se que a junção procura tornar mais evidente a relação entre o rap e a MPB, mediada pelo samba, que "Hino vira-lata" estabelece.

34 Para o clipe, assistir a: Emicida (20I3d). Para desdobramentos de "Samba do fim do mundo", escutar a faixa "Estilo livre” (de autoria de Emicida e Xuxa Levy), com Emicida e Nego Doido, no CD Sobre crianças, quadris, pesadelos e lições de casa (EMICIDA, 20I5), e também o disco A mulher do fim do mundo, lançado por Elza Soares (2OI5). 
navalha", gravada para o disco Raio X Brasil, o mesmo que lançou "Fim de semana no Parque", em I993: na voz de Edy Rock, ouvia-se que "A música negra é como uma grande árvore/ Com vários galhos e tal/ O rap é um, o reggae é outro,/ O samba também" (RACIONAIS MC'S, s. d.) ${ }^{35}$.

O quinto ponto prossegue na mesma direção. Contudo, nele também se evidenciam tensões, intensificadas até o limite em que se tornam diferenças bastante nítidas. Trata-se da convivência de rap e samba sem que se perceba a intenção de mistura (como havia nas obras do quarto ponto). O primeiro exemplo é o único registrado neste mapa cuja origem é o segmento de mercado do pagode. Em retribuição à participação de Netinho em "Fim de semana no Parque", o grupo Negritude Júnior gravou "Gente da gente" no disco homônimo, lançado pela EMI em I995 (NEGRITUDE JÚNIOR, 20I3). Mano Brown faria a introdução dizendo "a sua cara" na forma de rap:
3, 2, I, zero, contagem regressiva
$\mathrm{O}$ pesadelo no ar, Racionais, voz ativa
Não bebo do veneno que o sistema me traz
O controle remoto não me domina mais
Preto até o osso, cachorro loko, sempre firme
Mano Brown, bicho solto, longe do crime
É preciso ser malandro de atitude
Com vocês, Negritude.

Nesse momento, o rap é interrompido bruscamente pelo samba. A mudança é ostensiva. Até então, ouvíamos a batida feita por bateria eletrônica, sampler e scratches, com acentuação nas cabeças do segundo e do quarto tempo, em fórmula de compasso $4 / 4 \mathrm{e}$ andamento de $84 \mathrm{bpm}$. Essa levada de rap silencia, substituída pela batida do samba feita com maior densidade sonora (metais e percussão à frente), em fórmula de compasso $2 / 4$ e andamento de Io2 bpm. É como se a estética do samba, ao se impor, não deixasse espaço para a do rap.

A mudança também ocorre, como era de se esperar, no modo como as palavras passam a ser cantadas. Em lugar da dicção agressiva de Mano Brown, escutamos agora a dicção de Netinho de Paula, cujo principal elemento é o sorriso. Dessa forma, todos os versos do samba são embalados por um sentimento otimista. Acresce que a "gente da gente" exaltada por Netinho não é bem o "malandro de atitude" cantado por Brown, aquele personagem que não é dominado nem pelo "controle remoto" do sistema do crime, nem pelo "controle remoto" do sistema do trabalho. Ao contrário, a "gente da gente" se caracteriza pelo trabalho pontual e sem queixa, "vive a pegar no batente/ Com sol ou com chuva ou doente/ Sabe que tem que trabalhar". Assim, embora o final seja apoteótico em relação ao lugar em que o samba coloca o rap, os versos "Essa gente já sofre demais/ São tratados como animais/ E só querem um pouquinho de paz/ E precisam ouvir Racionais" estão destituídos da força crítica que a participação de Mano Brown anunciara.

Note-se, entretanto, que o sentido conformista de "Gente da gente" não se constrói

"Fio da navalha” é, como se diz coloquialmente, um blues instrumental. 
exatamente pela exaltação do(a) trabalhador(a), mas sim pela exaltação do trabalho, não importa se precário ou não, se desumanizador ou não. No rap "Júri racional" (de Mano Brown), gravado para o disco Raio X Brasil, o Racionais MC's condenava a "Ovelha branca da raça, traidor", e o refrão não deixava margem para dúvida: "Mas nosso júri é racional, não falha/ Não somos fãs de canalha” (RACIONAIS MC'S, s. d.). Ao se apropriar desses versos em "Gente da gente", Netinho modificou-lhes inteiramente o sentido, e a condenação, embora um tanto abstrata, se dirigiu a quem não vive para trabalhar de sol a sol: "Esse povo merece uma medalha/ Porque nunca foge da batalha/ Essa gente da gente não dá falha/ Porque não tem fã de canalha”. Assim, a "lição de viver" do Negritude, em "Gente da gente", é a de entregar-se de corpo e alma ao trabalho nas condições atuais em que ele se oferece. E o diálogo de Netinho e Brown, que encerra o fonograma sobre a base do samba, não modifica esse sentido. No sexto ponto, o assunto será ampliado.

Duas décadas adiante, o trabalho de Criolo desdobraria a convivência de rap e samba e a observação das diferenças entre os gêneros. Advirta-se, todavia, que os seus discos Nó na orelha (20II) e Convoque seu Buda (20I4) atravessaram de tal modo as fronteiras do "mundo do rap" que seria preciso investigar a fundo em que medida o seu "berço" permanece ativo, se é que permanece, na composição e na interpretação de sambas como "Linha de frente" (CRIOLO, 2OII) e "Fermento pra massa" (CRIOLO, 20I4) - algo impossível nos limites deste artigo ${ }^{36}$.

Pensamento semelhante se aplica a Espiral de ilusão, álbum inteiramente dedicado ao samba, lançado em 2017 (CRIOLO, 20I7). Em entrevista concedida ao jornal $O$ Estado de S.Paulo, Criolo afirmou que "Se você pegar quatro ou cinco letras deste disco, vai ver que na verdade é um rap que o Kleber (ele mesmo) fez. [...] Nos sambas 'Cria de favela' e 'Menino mimado', por exemplo, se você tirar o ritmo, vai perceber que aquilo é, na verdade, um rap” (CARVALHO, 20I7). Não custa reiterar que ideias como essa demandariam uma investigação específica. No âmbito deste mapeamento, porém, não há como desconsiderar que, à medida que o álbum ganha em simpatia, perde em contundência. Pois, quando se escutam versos como "Então pare de correr na esteira e vá correr na rua" ou "Meninos mimados não podem reger a nação", a crítica endereçada a parcelas da classe média e da classe alta é feita de modo doce ${ }^{37}$. E quando se escuta a quadra "Menino, você não pode voltar/ Porque a biqueira não é seu lugar/ Quem vai lucrar com essa patifaria/É gente da alta na papelaria”, o canto, jogando com o ritmo do batuque, injeta graça à crítica ${ }^{38}$.

Em síntese, conforme o disco vincula o artista ao "mundo do samba", afasta-o

36 Na passagem, faço referência aos versos "A ditadura segue, meu amigo Milton/ A repressão segue, meu amigo Chico/ Me chamam Criolo, o meu berço é o rap/ Mas não existe fronteira pra minha poesia, Pai”, entoados no vídeo “Criolo Doido - Cálice”, difundido no YouTube a partir de 9 de setembro de 20 o (CRIOLO, 20I0). Para a análise deste vídeo e a discussão de sua relação com a MPB, consultar: Garcia (20I4). Agradeço a Antonio Eleilson Leite a conversa informal que mantivemos, em junho de 20I4, sobre o assunto.

37 Os versos são de "Menino mimado", de autoria de Criolo (20I7). Sem esquecer a expressão doce que atravessa o canto, uma vez que o sujeito da canção se dirige a "você”, e que o título do samba também está no singular, é incontornável cogitar na personalidade pública a quem melhor caberia a crítica.

38 Os versos são de "Cria de favela", de autoria de Criolo (20I7). 
do "mundo do rap". E esse movimento se torna mais lógico se levarmos em conta que Espiral de ilusão radicaliza um dos aspectos que o caminho traçado por Nó na orelha e Convoque seu Buda definiu: o do talento de Criolo para fazer parte do clube restrito da $\mathrm{MPB}^{39}$.

\section{“SEM ESQUeCER DE USAR A PARTE CEREBRAL”}

No sexto ponto, reúnem-se divergências, afastamentos e disputas entre o rap e o samba. Em uma tentativa de esquematização, dividirei a exposição em três itens.

O primeiro deles registra a "relação conflituosa entre rap e as Escolas de Samba", ao longo da década de I990, conforme pesquisa do antropólogo João Batista de Jesus Félix (2000) . A divergência teria se formado na soma de quatro questões: a) o choque entre a militância antirracista dos rappers paulistanos e a opinião por eles partilhada de que "o carnaval, maior expressão das Escolas de Samba, é hoje [...] a melhor prova do alheamento frente à discriminação que o negro sofre em nossa sociedade”; b) a crítica, enunciada por Seu Nenê ("presidente e um dos fundadores da Escola de samba Nenê da Vila Matilde"), de que os rappers praticam uma cultura que "não é brasileira"; c) as disputas entre três visões das relações étnicas implicadas na prática do samba: o entendimento de dirigentes de escolas de que "o samba atualmente é mais respeitado e frequentado pelos brancos, mas continua sendo uma "cultura negra"; a crítica do movimento hip-hop de que o samba "era uma cultura negra”, mas atualmente não é mais; e a noção, defendida pelo conjunto do Movimento Negro, de que o samba permanece sendo "uma cultura negra"; d) a questão geracional, uma vez que, para os dirigentes das escolas de samba, "a maioria dos rappers estão na faixa dos vinte anos de idade", em conexão com as diferenças entre "a história muito longa" do samba, a qual justificaria "as suas posições atuais", e a experiência recente da cultura hip-hop, desenvolvida em São Paulo desde a década anterior, a de I980 (FÉLIX, 2000, p. IOO-IOI) ${ }^{40}$.

Já o segundo item considera os conflitos que resultaram de dois grandes sucessos que aconteceram em paralelo, ainda nos anos I990: o do samba romântico de grupos como Negritude Júnior ou Art Popular no mercado hegemônico, quando o pagode se tornou, "seguramente, o segmento musical mais importante da década" (VICENTE, 20I4, p. I88); e o do rap do Racionais MC's em um dos mercados alternativos, quando o grupo se firmou como a principal referência das culturas negras e periféricas no Brasil. Conflitos que iluminam as tensões encapsuladas em "Gente da gente".

Em I999, quando a revista Istoé perguntou a Netinho se concordava com as posições de Mano Brown, ele respondeu:

39 Sobre o assunto, consultar: Garcia (20I4). Registre-se pelo menos mais uma canção que justapôs samba e rap, sem nenhuma intenção de mistura, e que não será analisada neste artigo: “Quanto vale o show”, de Mano Brown (RACIONAIS MC'S, 20I4).

40 Ressalte-se que, segundo João Batista de Jesus Félix, frequentadores e frequentadoras dos bailes tanto gostavam de rap quanto compareciam às quadras: "as populações desses dois bailes parecem não se preocupar com essa relação conflituosa entre rap e Escolas de Samba” (FÉLIX, 2000, p. IOI). 
Os Racionais se preocupam com o negro da periferia. O Negritude se preocupa com o povo pobre da periferia. Na frente, vamos nos encontrar com a mesma proposta porque a maioria dos pobres é negra. Mas eu não posso falar só para os negros. [...] O movimento hip-hop é hoje uma coisa muito forte e consciente, que cresce em todo o País. Vamos propor uma união do rap com o samba. A ideia é que haja um meio-termo entre o discurso radical e um mais acessível. Esse movimento vai revolucionar o Brasil. (NETINHO, I999).

Salvo desconhecimento meu, o projeto não foi levado adiante a não ser por canções que se propuseram a misturar ou a justapor samba e rap, como as que foram acima comentadas, e logicamente não estou dizendo que a inspiração para alguma delas tenha vindo da entrevista de Netinho. De todo modo, é possível indicar pelo menos uma das grandes dificuldades para a "união do rap com o samba" naquele momento: as diferentes relações que as formas de um gênero e do outro estabeleceram com seus públicos.

Escrevendo sobre a apresentação do Racionais MC's no comício do Partido dos Trabalhadores (PT), em Io de maio de I999, a psicanalista Maria Rita Kehl observou que "a força dos grupos de rap não vem de sua capacidade de excluir, de colocar-se acima da massa e produzir fascínio, inveja". A força do rap "vem de seu poder de inclusão, da insistência na igualdade entre artistas e público, todos negros, todos de origem pobre, todos vítimas da mesma discriminação e da mesma escassez de oportunidades” (KEHL, 2000, p. 2I2).

Por sua vez, o pagode desenvolveu características que o colocaram, na análise do linguista Luiz Tatit, em linha com o sertanejo e o axé, outros dois segmentos de sucesso no mercado hegemônico nos anos I990. Uma delas era o planejamento de um produto no qual som, imagem e espetáculo fossem indissociáveis e "programados para uma fruição a distância”, nas “arquibancadas de imensos ginásios (ou estádios), ao ar livre, nos telões e, obviamente, na telinha das redes de tevê". Outra, "o propósito explícito de agradar a um público desprevenido que se relacionava com a canção 'em bloco”, a quem o pagode "proporcionava alegria, emoção e pronto" (TATIT, 2004, p. 235-236). Em suma, características que mantinham o público na função de consumidor, dispensavam o “desmembramento crítico" da obra (TATIT, 2004, p. 236), reforçavam o conformismo e produziam fascínio ${ }^{4 \mathrm{I}}$. Adiante, a discussão será vista de outro ângulo.

4I Para outras análises do samba romântico nos anos I990, consultar: D’Andrea (20I3a, p. 74-79), Lopes (2005, p. I76-I85), Trotta (20I5) e Vicente (20I4, p. I9I-I93, 2I6-2I7). Em 2005, seria lançado o DVD Netinho de Paula in concert (NETINHO DE PAULA, 2005). Mano Brown e Ice Blue participam de “Gente da gente” acompanhados, no palco, por alguns amigos. Embora estejam lado a lado, é ostensiva a divisão entre o "mundo do pagode” e o "mundo do rap”. Note-se ainda a multidão que assiste ao show, gravado em Carapicuíba (“Caracas City”). A partir desse vídeo e do DVD Iooo trutas Iooo tretas, gravado pelos Racionais em 2004, no Sesc Itaquera, outros aspectos poderiam ser examinados (RACIONAIS MC’S, 2006). Para ficar somente em três: a) as diferenças entre a presença física de MCs e a de sambistas; b) a noção de "que malandragem de verdade é viver" em um espetáculo de pagode, como o que se vê com Netinho de Paula em “Gente da gente”, e em um show de rap, como o que se vê quando o Racionais canta "Fórmula mágica da paz" (de Mano Brown); c) os comportamentos distintos das duas plateias, a de samba romântico e a de "rap-político" - a expressão é de Azevedo \& Silva (I999, p. 80). 
O terceiro e último item deste sexto ponto traz a crítica de que "'muitas dessas nossas mulheres do hip-hop são mulheres negras, e a gente ainda tem esse estigma que a mulher negra é mulata pra sambar”" (MATSUNAGA, 2006, p. I76). A crítica não é endereçada só ao carnaval, mas também ao "padrão de coreografias provocantes realizadas por dançarinas em roupas sumárias”, desde a década de I990, em segmentos do mercado hegemônico como o forró ou o axé (VICENTE, 20I4, p. I9I). Frente a "esse estigma" e ao comportamento de "Quem achou que somos mercadoria que você contrata e alicia/ Para satisfazer o seu prazer pela orgia”, já em 20I4, as rappers do grupo Odisseia das Flores cantavam "Sem curva na ideia": "Entra em choque, Odisseia não precisa rebolar pra ter ibope/ Estamos falando de postura, não do tamanho do seu short/ Uma mulher pode e deve ser sensual/ Sem esquecer de usar a parte cerebral" (ODISSEIA DAS FLORES, 20I4). Sem levar adiante uma questão que ultrapassaria em muito a finalidade deste artigo, note-se que o conflito se adensa pelo fato de que hoje "funkeiras defendem a liberdade corporal como sua aliada no dia a dia", reivindicam "que o mundo respeite a liberdade dos nossos corpos, nossas vestimentas e nosso jeito" e afirmam o propósito de "educar nossas garotas com um misto de consciência feminista e audácia” (PRADO, 20I7) ${ }^{42}$.

\section{"NO TEU SORRISO SONHEI"}

Como não terá escapado a uma leitura atenta, este artigo busca sistematizar um amplo movimento em processo. Assim, é coerente que se encerre sem conclusão e tendo, como sétimo ponto, uma noção cujo debate é incipiente.

Trata-se da importância complementar que o rap e o samba romântico tiveram para a "construção identitária da masculinidade negra periférica" de adolescentes e jovens na década de I990. Segundo Ícaro Rodrigues da Rocha, quando sujeitos líricos do pagode dos anos I990 expressaram "fragilidades do seu mundo interior", acabaram oferecendo um contraponto à "representação do homem negro na sociedade brasileira, [a qual] sempre vem carregada de muitos estereótipos ligados" à violência (ROCHA, no prelo).

Nessa perspectiva, ao mesmo tempo que o Racionais MC's forjou a imagem de "os quatro pretos mais perigosos do Brasil”, fundamental para o revide simbólico do rap, para a afirmação da dignidade do jovem negro de periferia e para a crítica da violência que estrutura a sociedade brasileira (GARCIA, 2003), o samba romântico contribuiu para a educação sentimental de "jovens na periferia" cantando, nas "paradas de sucesso", os "encantos e desencantos da experiência amorosa” (ROCHA, no prelo).

Até o momento, salvo engano, apenas uma obra artística trabalhou com esta noção: a peça teatral Farinha com açúcar ou Sobre a sustança de meninos e homens, do Coletivo

42 É oportuno indicar dois textos que foram estudados durante este mapeamento e que poderiam contribuir para a discussão do feminismo no rap ou no funk: o capítulo III, "Exploração sexual da mulher africana", do livro O genocídio do negro brasileiro: processo de um racismo mascarado, de Abdias Nascimento (2017); e a personagem “Mulher-Rainha”, representada por Aysha Nascimento no espetáculo Movimento número I: $o$ silêncio de depois..., dramaturgia de Jé Oliveira (COLETIVO NEGRO, 20I5, p. 39-60). 
Negro, apresentada desde 20I6. Escrito, dirigido e representado por Jé Oliveira, o espetáculo resultou de um processo de pesquisa durante o qual foram entrevistados doze "homens negros de diversas idades e ocupações". A partir das entrevistas, Farinha com açúcar... se tornou um tributo ao Racionais MC’s (OLIVEIRA, 20I8).

Nessa peça-show, a (re)criação da vida possível se dá a partir de uma cultura musical negra. No centro da constelação, como se espera, está o rap. Mas, em lugar que ainda precisa ser mais bem localizado pela crítica, se encontra o samba romântico, narrando os primeiros encontros amorosos do personagem "Homem", um tipo de sobrevivente ${ }^{43}$.

\section{SOBRE O AUTOR}

WALTER GARCIA é professor associado do Instituto de Estudos Brasileiros da Universidade de São Paulo (IEB/USP).

E-mail: waltergarcia@usp.br

\section{REFERÊNCIAS}

ALVES, César. Pergunte a quem conhece: Thaíde. São Paulo: Labortexto Editorial, 2004.

ALVES, Francisco; REIS, Mário. Se você jurar. Francisco Alves \& Mário Reis (I93I). Disponível em: <https://www.youtube.com/watch?v=qlzSds5Yc3E >. Publicado em: I5 fev. 20 Ir. Acesso em: I6 out. 2017. [Fonograma lançado em I93I.]

AMARAL, Marina. Mais de 50.000 manos. Caros Amigos Especial: movimento Hip Hop. São Paulo, n. 3, p. 4-8, I998.

. De volta para o futuro. Caros Amigos Especial: Hip Hop hoje. São Paulo, n. 24, p. 4-6, jun. de 2005.

ARAGÃO, Jorge. Malandro. Autores: Jorge Aragão, Jotabê. Disponível em: <http://jorgearagao.com/discografia >. Acesso em: 7 ago. 20I7. [Fonograma lançado em I983.]

ART POPULAR. O canto da razão. I993. Disponível em: <https://www.youtube.com/watch?v=Bos6tkYO -8w>. Publicado em: 26 mai. 20I7. Acesso em: I3 fev. 20I8. [LP lançado em I993.]

ASSEF, Claudia. Todo DJ já sambou: a história do disc-jóquei no Brasil. São Paulo: Conrad Editora do Brasil, 2003.

AZEVEDO, Amailton Magno Grillu; SILVA, Salloma Salomão Jovino da. Os sons que vêm das ruas: a música como sociabilidade e lazer da juventude negra urbana. In: ANDRADE, Elaine N. de (Org.). Rape educação, rap é educação. São Paulo: Summus/Selo Negro, I999, p. 65-8I.

AZEVEDO, Amailton Magno; SILVA, Salomão Jovino da. Um raio X do movimento Hip-Hop. Revista da Asso-

43 A peça-show conta com a participação de uma banda. Até o momento em que escrevo, ela já foi integrada por: Cássio Martins (baixo); DJ Tano Záfrica’Brasil ou DJ Wojtila (samples e scratches); Fernando Alabê (percussão e bateria); Mauá Martins (teclados, MPC e voz); Melvin Santhana (guitarra, violão e voz). Em algumas das apresentações, houve a participação especial de KL Jay, DJ do Racionais MC's. 
ciação Brasileira de Pesquisadores/as Negros/as (ABPN). [S.l.], v. 7, n. I5, fev. 2015, p. 2I2-239. Disponível em: <http://abpnrevista.org.br/revista/index.php/revistaabpnI/article/view/I22 >. Acesso em: 2 ago. 2017.

BARBOSA, Marco Antonio. Mensagens numa batida diferente. Publicado em: 27 jul. 20oI. Disponível em: <http://cliquemusic.uol.com.br/materias/ver/mensagens--numa-batida-diferente>. Acesso em: 7 mar. 2018.

BEN, Jorge. Samba esquema novo. Universal, 5I8II52, 200I. I CD. [LP lançado em I963.] BÉTHUNE, Christian. Pour une esthétique du rap. Paris: Klincksieck, 2004.

BIONDI, Pedro. O rap agradece. Caros Amigos Especial: movimento Hip Hop. São Paulo, n. 3, p. 20-2I, I998. BOTELHO, Guilherme, GARCIA, Walter, ROSA, Alexandre. Três raps de São Paulo: "Política”, Athalyba -Man (I994); “O menino do morro”, Facção Central (2003); "Mil faces de um homem leal (Marighella)", Racionais MC’s (20I2). In: LACERDA, Marcos (Org.). Música. Rio de Janeiro: Funarte, 20I6, p. I7I-20I. (Ensaios brasileiros contemporâneos).

BUARQUE, Chico. Almanaque. Ariola, 201 640, I98I. I LP. . Pedaço de mim. Universal, 73I45860II2, 200I. I CD.

CAMPOS, Marcelo da Silveira. Comunidade Samba da Vela: "Que a divina luz ilumine todas as criações". Plural, Revista de Ciências Sociais. São Paulo, v. 20, n. I, 20I3, p. I2I-I38. http://dx.doi.org/Io.II606/ issn.2I76-8099.pcso.2013.74418.

CANDIDO, Antonio. O estudo analítico do poema. 3. ed. São Paulo: Humanitas Publicações/FFLCH-USP, I996. CARVALHO, João Paulo. Criolo se reinventa, aposta no samba e faz disco com dez músicas inéditas. O Estado de S.Paulo, 28/4/20I7. Disponível em: <http://cultura.estadao.com.br/noticias/musica,criolo-se-reinventa-aposta-no-samba-e-faz-disco-com-dez-musicas-ineditas,700oI755247>. Acesso em: 2I ago. 2017. COLETIVO NEGRO. Negras dramaturgias. São Paulo: Coletivo Negro/Cooperativa Paulista de Teatro/ Programa Municipal de Fomento ao Teatro da Prefeitura de São Paulo, 2015.

CONSCIÊNCIA HUMANA. Consciência Humama - o9 Território Leste (Part. Beth Carvalho). Disponível em: 〈https://www.youtube.com/watch?v=yDoXQQxWRQE >. Publicado em: 2 jan. 20Io. Acesso em: 2I ago. 20I7. [Fonograma lançado em 2003.]

CRIOLO. Criolo Doido - Cálice. Disponível em: 〈https://www.youtube.com/watch?v=akZYo-6RsoA 〉. Publicado em: 9 set. 20Io. Acesso em: 30 jun. 20I8. [Vídeo lançado em 20Io.]

. Nó na orelha. Independente, CRoo03, $20 \mathrm{II}$.

. Convoque seu Buda. Oloko Records, 060254709342, 2014.

Espiral de ilusão. Disponível em: <http://criolo.net/espiral/. Acesso em: 2I ago. 20I7. [Disco lançado em 20I7.]

CRIOLO. REVISTA CRIOLO / VOL. I. Disponível em: 〈http://criolo.net/espiral〉. Acesso em: 2I ago. 20I7a.

CUNHA, Fabiana Lopes da. Da marginalidade ao estrelato: o samba na construção da nacionalidade (I9I7I945). São Paulo: Annablume, 2004.

D’ANDREA, Tiarajú Pablo. A formação dos sujeitos periféricos: cultura e política na periferia de São Paulo. 2013. 309 f. Tese (Doutorado em Sociologia) - Faculdade de Filosofia, Letras e Ciências Humanas, Universidade de São Paulo, 2013. [2013a]

"Fim de semana no parque”: vinte anos. Le Monde Diplomatique Brasil, 돼1_/20I3. Disponível em: 〈http://diplomatique.org.br/fim-de-semana-no-parque-vinte-anos〉. Acesso em: 2 ago. 20I7. [20I3b]

EMICIDA. O glorioso retorno de quem nunca esteve aqui. Laboratório Fantasma/ Pommelo Distribuições e Editorações, 2013. I CD. [2013a]

. Emicida - Trepadeira (Feat: Wilson das Neves). Disponível em: <https://www.youtube.com/watch?v=ShnL-2LeCj4>. Publicado em: 22 ago. 2013. Acesso em: I6 out. 20I7. [2013b] 
. Emicida - Hino Vira-Lata (Feat: Quinteto em Branco e Preto).Disponível em: <https://www.youtube. com/watch?v=TkSyIwGuKd4>. Publicado em: 22 ago. 20I3. Acesso em: I6 out. 20I7. [20I3c]

. Emicida - Samba do fim do Mundo (Feat: Fabiana Cozza \& Juçara Marçal). Disponível em: <https:// www.youtube.com/watch?v=Kkik332iUnI >. Publicado em: 22 ago. 20I3. Acesso em: I6 out. 20I7. [20I3d] . Sobre crianças, quadris, pesadelos e lições de casa. Laboratório Fantasma, 88875I42322, 20I5. I CD.

. O glorioso retorno de quem nunca esteve aqui. Disponível em: $\langle$ http://www.emicida.com/discografia/o-glorioso-retorno-de-quem-nunca-esteve-aqui-20I3〉. Acesso em: I6 out. 2017.

FÉLIX, João Batista de Jesus. Chic Show e Zimbabwe e a construção da identidade nos bailes black paulistanos. 2000. 202 f. Dissertação (Mestrado em Antropologia Social). Faculdade de Filosofia, Letras e Ciências Humanas, Universidade de São Paulo, 2000.

. Hip Hop: cultura e política no contexto paulistano. 206 f. Tese (Doutorado em Antropologia Social). Faculdade de Filosofia, Letras e Ciências Humanas, Universidade de São Paulo, 2005.

FENERICK, José Adriano. Nem do morro nem da cidade: as transformações do samba e a indústria cultural (I920-I945). São Paulo: Annablume/Fapesp, 2005.

GARCIA, Walter. Ouvindo Racionais MC’s. Teresa. São Paulo, n. 4/5, 2003, p. I66-I80. Disponível em: <http:// dx.doi.org/Io.II606/issn.2447-8997.teresa.2003.II6377>. Acesso em: 7 ago. 2017.

. Sobre uma cena de “Fim de semana no Parque”, do Racionais MC's”. Estudos Avançados. São Paulo, v. 25, n. 7I, jan.-abr. 20II, p. 22I-235. http://dx.doi.org/Io.I590/SoI03-40I420II000I000I5.

. Elementos para a crítica da estética do Racionais MC’s (I990-2006). Idéias. Campinas, v. I, n. 7, 2o semestre de 20I3, p. 8I-IIo. Disponível em: <https://periodicos.sbu.unicamp.br/ojs/index.php/ideias/ article/view/8649382/I5937>. Acesso em: I6 out. 2017.

. Notas sobre “Cálice” (20I0, I973, I978, 20II). Música Popular em Revista, ano 2, v. 2, Campinas, jan./ jun. 20I4. p. IIO-I5O. Disponível em: <https://www.publionline.iar.unicamp.br/index.php/muspop/ article/view/280 >. Acesso em: 2 ago. 2017.

HOUAISS, Antônio, VILLAR, Mauro de Salles. Dicionário Houaiss da Língua Portuguesa. Rio de Janeiro: Objetiva, 200I.

INSTITUTO. Instituto - Coleção Nacional. Disponível em: <https://www.youtube.com/watch?v=aDggUnWvoKk >. Publicado em: I5 jan. 20I3. Acesso em: 2I ago. 2017.

KEHL, Maria Rita. A fratria órfã: o esforço civilizatório do rap na periferia de São Paulo. In: KEHL, M. R. (Org.). Função fraterna. Rio de Janeiro: Relume Dumará, 2000, p. 209-244.

LEITÃO, Sérgio Sá. Metalúrgicos do ABC criam selo e lançam I2 LPs. Folha de S.Paulo, Ilustrada, I9/5/I99I, p. 5-I. [I99Ia]

. Rap nacional domina os bailes blacks. Folha de S.Paulo, caderno Ilustrada, I9/5/I99I, p. 5-I. [I99Ib]

LEITE, Antonio Eleilson. Mesmo céu, mesmo CEP: produção literária na periferia de São Paulo. 20I4. 228 f. Dissertação (Mestrado em Filosofia). Programa de Pós-Graduação em Estudos Culturais. Escola de Artes, Ciências e Humanidades, Universidade de São Paulo, 20I4.

LIMA, Mariana Semião de. Rap de batom: família, educação e gênero no universo rap. 224 f. Dissertação (Mestrado em Educação). Faculdade de Educação, Universidade Estadual de Campinas, 2005.

LOPES, Nei. Partido-alto: samba de bamba. Rio de Janeiro: Pallas, 2005.

MANO BROWN. Mano Brown. Teoria e Debate, São Paulo, n. 46, nov./200o-jan. 200I, sem paginação.

Entrevista concedida a Spensy Pimentel. Disponível em: <https://teoriaedebate.org.br/2000/II/I5/ mano-brown >. Acesso em: 2I ago. 2017.

. Papo reto: hoje, Mano Brown é paz e amor. Vip, 2I ago. 20I7. Entrevista concedida a Marcos Lauro. Disponível em: 〈https://vip.abril.com.br/cultura/papo-reto-hoje-mano-brown-e-paz-e-amor $>$. Acesso em: 6 fev. 2018. 
. Mano Brown, um sobrevivente do inferno - Entrevista completa. Disponível em: <https://www. youtube.com/watch?v=gMT9cXizDYQ>. Publicado em: 28 fev. 20I8. Acesso em: 2 mar. 2018.

MATSUNAGA, Priscila Saemi. Mulheres no hip hop: identidades e representações. 209 f. Dissertação (Mestrado em Educação). Faculdade de Educação, Universidade Estadual de Campinas, 2006.

MORAES, Vinicius de, LARA, Odette. Vinicius e Odette Lara. Universal Music, 73 I45 I20572 - SET 73I45606862, 200I. I CD. [LP lançado em I963.]

MÚSICA PARA RITUAIS de antropofagia tecnocultural. Direção de Belisário Franca. Roteiro e pesquisa de Hermano Vianna. Direção musical de Beto Villares. Giros Produções/Produções Abril/Abril Entretenimento, 200o. Programa $\mathrm{n}^{\circ} 7$ da série Música do Brasil.

NAPOLITANO, Marcos. A música popular brasileira (MPB) dos anos 70: resistência política e consumo cultural. Actas del V Congresso Latinoamericano IASPM, 2002. Disponível em:

<http://www.educadores.diaadia.pr.gov.br/arquivos/File/fevereiro2oI2/historia_artigos/2napolitano7o_ artigo.pdf $>$. Acesso em: 2 abr. 20I8. [2002a]

. História er música: história cultural da música popular. Belo Horizonte: Autêntica, 2002. [2002b]

NASCIMENTO, Abdias. O genocídio do negro brasileiro: processo de um racismo mascarado. I. reimpressão da 2. ed. São Paulo: Perspectiva, 20I7.

NASCIMENTO, Érica Peçanha do. É tudo nosso!: produção cultural na periferia paulistana. 223 f. Tese (Doutorado em Antropologia). Faculdade de Filosofia, Letras e Ciências Humanas, Universidade de São Paulo, 20II.

NDEE NALDINHO. Você tem que acreditar. Disponível em: <https://www.youtube.com/watch?v=XC47Io4443g>. Publicado em: 5 fev. 20I7. Acesso em: 2I ago. 20I7. [LP lançado em I997.]

NDEE NALDINHO, ART POPULAR. A arte do gueto. Disponível em: <https://www.youtube.com/watch?v=gX4UuoMCZOI>. Publicado em: 9 dez. 2009. Acesso em: 2I ago. 20I7. [Fonograma lançado em 2009.]

NEGRITUDE JÚNIOR. Jeito de seduzir (I992) completo S \& P 90. Disponível em: <https://www.youtube.com/ watch?v=QsMOG4soXNc >. Publicado em: I7 out. 20I4. Acesso em: I3 fev. 20I8. [LP lançado em I992.] . Negritude Jr - Gente da gente. Disponível em: 〈https://www.youtube.com/watch?v=888igIDWq_8〉. Publicado em: 2 fev. 20I3. Acesso em: I3 fev. 20I8. [Fonograma lançado em I995.]

NETINHO DE PAULA. Netinho de Paula In Concert / 2005 Completo \#RS. Disponível em: <https://www. youtube.com/watch?v=OY6kC5b9AWQ>. Publicado em: I3 out. 20I7. Acesso em: I3 fev. 20I8. [DVD lançado em 2005.]

NETINHO (José de Paula Neto). O mano do pagode. Istoé, n. I.576, I5/I2/I999. Disponível em: <https://istoe. com.br/28305_O+MANO+DO+PAGODE+>. Acesso em: 6 fev. 2018.

NOS TEMPOS da São Bento. Direção de Guilherme Botelho. São Paulo: Suatitude, 20Io. I DVD.

ODISSEIA DAS FLORES. Odisseia das Flores - Sem curva na ideia (Vídeo Oficial). Disponível em: <https:// www.youtube.com/watch?v=uA-756YNCkA>. Publicado em: 24 fev. 20I4. Acesso em: I3 fev. 2018. [Vídeo lançado em 20I4.]

OLIVEIRA, Jé. Farinha com açúcar ou Sobre a sustança de meninos e homens. Belo Horizonte: Javali, 2018.

PAGODINHO, Zeca. Zeca Pagodinho - Vai Vadiar. Disponível em: <https://www.youtube.com/watch?v=uFzsfe5EEaE >. Publicado em: Io dez. 20I0. Acesso em: I6 out. 20I7. [Videoclipe lançado em I998.]

PINTO, Tania Regina. Sharylaine, a pioneira do rap feminino em Sampa. Disponível em: <http://primeirosnegros.blogspot.com.br/20I7/o3/sharylaine-pioneira-do-rap-feminino-em.html >. Publicado em: 6 mar. 20I7. Acesso em: I3 fev. 2018.

POSSE MENTE ZULU. Sou negrão ao vivo I995. Disponível em: <https://www.youtube.com/watch?v=F6PoFoksIuw >. Publicado em: 27 jun. 20I5. Acesso em: 7 mar. 20I8. [Videoclipe lançado em I995.]

PRADO, Renata. Massa funkeira engajada. Disponível em: <https://hysteria.etc.br/ler/massa-funkeira -engajada>. Publicado em: 30 out. 2017. 
QUINTILIANO, Rachel. Álbum: Você tem que acreditar (Ndee Naldinho). Mundo da Rua: catálogo do rap nacional. Disponível em: 〈https://mundodarua.wordpress.com/tag/ndee-naldinho >. Publicado em: 7 nov. 20Io. Acesso em: 2I ago. 2017.

RACIONAIS MC'S. Racionais MC's. RDS Fonográfica/ Zimbabwe Records, ZBCDoI5, s.d. I CD. [Coletânea dos LPs Raio X Brasil, lançado em I993, Escolha seu caminho, lançado em I992, e Holocausto urbano, lançado em I990.]

. I000 trutas I000 tretas. Cosa Nostra, CN 007, 2006. I DVD.

. Cores e Valores. Cosa Nostra Fonográfica/ Boogie Naipe/ Radar Records, RAD 44I5, 20I4. I CD.

RAPPIN' HOOD. Rappin' Hood em Sujeito homem. Trama, T400/245-2, 200I. I CD.

. Rappin' Hood em Sujeito homem 2. Trama, 993-2, 2005. I CD.

ROCHA, Ícaro Rodrigues da. Pagode 90: a construção da afetividade do homem negro periférico. In: FAUSTINO, Carmen; FREITAS, Maitê; VAZ, Patrícia (Org.). Sambas e dissembas. São Paulo, n. 2, no prelo. (Sambas escritos).

ROSA, Waldemir. Homem preto do gueto: um estudo sobre a masculinidade no rap brasileiro. $97 \mathrm{f}$. Dissertação (Mestrado em Antropologia Social). Instituto de Ciências Sociais, Universidade de Brasília, 2006. SANDRONI, Carlos. Feitiço decente: transformações do samba no Rio de Janeiro (I9I7-I933). 2. ed., ampliada. Rio de Janeiro: Zahar, 2012.

. Adeus à MPB. In: CAVALCANTE, Berenice, STARLING, Heloisa, EISENBERG, José (Org.). Decantando a República: outras conversas sobre os jeitos da canção. Rio de Janeiro: Nova Fronteira/Faperj; São Paulo: Editora Fundação Perseu Abramo, 2004, p. 23-35.

SANTA ROSA, Giovanni. Discurso do rap, discursos da imprensa: Racionais MC’s nas páginas da Folha de S.Paulo. I36 f. Trabalho de Conclusão de Curso (Comunicação Social - habilitação em Jornalismo). Escola de Comunicações e Artes, Universidade de São Paulo, 2016.

SEGRETO, Marcelo. A linguagem cancional do rap. I50 f. Dissertação (Mestrado em Linguística). Faculdade de Filosofia, Letras e Ciências Humanas, Universidade de São Paulo, 2015.

SILVA, José Carlos Gomes da. Rap na cidade de São Paulo: música, etnicidade e experiência urbana. 286 f. Tese (Doutorado em Ciências Sociais). Instituto de Filosofia e Ciências Humanas, Universidade Estadual de Campinas, I998.

. Arte e educação: a experiência do movimento Hip Hop paulistano. In: ANDRADE, Elaine N. de (Org.). Rap e educação, rap é educação. São Paulo: Summus/Selo Negro, I999, p. 23-38.

SOARES, Elza. Elza Soares - A Mulher do Fim do Mundo (20I5). Disponível em: <https://www.youtube.com/ watch?v=I38EcMJX8A8>. Publicado em: 3 out. 20I5. Acesso em: I6 out. 20I7. [Disco lançado em 20I5.] SOARES, Elza, NEVES, Wilson das. Elza Soares Wilson das Neves - LP Baterista Wilson das Neves - Album Completo/Full Album. Disponível em: 〈https://www.youtube.com/watch?v=JmqjG6owIbo >. Publicado em: 8 ago. 20I4. Acesso em: I6 out. 20I7. [LP lançado em I968.]

SODRÉ, Muniz. Samba, o dono do corpo. 2. ed. Rio de Janeiro: Mauad, I998.

THAÍDE, DJ HUM. Thaíde \& Dj Hum - Sr. Tempo Bom (Vídeo-Clipe OFICIAL) [HD]. Disponível em: <https:// www.youtube.com/watch?v=wOimVlATRI4>. Publicado em: I7 abr. 20I7. Acesso em: 2 ago. 2017. [Videoclipe lançado em I996.]

TATIT, Luiz. O século da canção. Cotia: Ateliê Editorial, 2004.

TONI C. Um bom lugar: biografia oficial de Mauro Mateus dos Santos-Sabotage. São Paulo: LiteraRUA, 20I3. TROTTA, Felipe. Samba and the music market in Brazil in I990s. In: ULHÔA, Martha Tupinambá de; AZEVEDO, Cláudia; TROTTA, Felipe (Org.). Made in Brazil: studies in popular music. New York: Routledge, 20I5, p. 43-54.

VÁRIOS. Equipe Kaskata’s - A ousadia do rap (I987) [Álbum Completo]. Disponível em: <https://www. 
youtube.com/watch?v=QIiHP3io3uA>. Publicado em: 29 out. 2013. Acesso em: I3 fev. 2018. [LP lançado em I987.]

. Coletânea Hip Hop cultura de rua. Vol. I Álbum Completo [I988]. Disponível em: <https://www. youtube.com/watch?v=lBy7htKtXmk>. Publicado em: 6 fev. 20I7. Acesso em: I3 fev. 20I8. [LP lançado em I988a.]

. Coletânea O som das ruas. Álbum Completo [I988]. Disponível em: <https://www.youtube.com/ watch?v=BSiv3WWmTNk>. Publicado em: 6 fev. 20I7. Acesso em: I3 fev. 20I8. [LP lançado em I988b.] . Coletânea Consciência black. Vol. I Álbum Completo [I989]. Disponível em: <https://www.youtube. com/watch?v=4khNAOIb5gA >. Publicado em: 6 fev. 20I7. Acesso em: I3 fev. 20I8. [LP lançado em I989.] . Os grandes sambas da história, vol. Io. Editora Globo/ BMG/ RCA, 7432152777-2, I997. I CD.

VICENTE, Eduardo. Da vitrola ao iPod: uma história da indústria fonográfica no Brasil. São Paulo: Alameda, 20I4. 